\title{
Kosmetik Herbal yang Berpotensi sebagai Pemutih Kulit Alami
}

\author{
Danaparamita Bashirah ${ }^{1, *}$, Norisca Aliza Putriana² \\ ${ }^{1}$ Program Studi Sarjana Farmasi, Fakultas Farmasi, Universitas Padjadjaran \\ ${ }^{2}$ Departemen Farmasetika dan Teknologi Farmasi, Fakultas Farmasi, Universitas Padjadjaran \\ *email: danaparamita@rocketmail.com \\ (Submit 9/8/2019, Diterima 12/8/2019)
}

\begin{abstract}
Abstrak
Kosmetik herbal semakin berkembang dan disukai oleh masyarakat. Hidrokuinon sebelumnya seringkali digunakan sebagai bahan utama kosmetik pemutih, namun penggunaannya kini telah dilarang dengan alasan masalah keamanan. Kosmetik herbal mengandung bahan alami yang relatif aman dan memiliki beragam manfaat, salah satunya sebagai pemutih kulit. Produk ini bekerja dengan cara mereduksi pigmen melanin yang terdapat dalam kulit. Review ini bertujuan untuk menyediakan informasi mengenai tanaman yang mengandung zat aktif dengan efek pemutih kulit. Review ini mengambil dari beberapa jurnal nasional maupun internasional yang dirilis dalam rentang waktu sepuluh tahun terakhir yaitu mulai tahun 2009 hingga 2019. Terdapat berbagai tanaman yang memiliki aktivitas untuk memutihkan kulit dengan cara menginhibisi aktivitas tirosinase. Tanaman yang memiliki potensi sebagai pemutih kulit diantaranya yaitu temulawak, akar manis, bengkuang, raspberry, ceri acerola, sophora japonica, delima, hijiki, marbei putih, nangka, dan alamanda.
\end{abstract}

Kata Kunci : kosmetik, herbal, pemutih

\section{Outline}

- Pendahuluan

- Metode

- Hasil

- Pembahasan

- Temulawak

- Akar manis

- Bengkuang

- Raspberry

- Ceri Acreola

- Sophora Japonica

- Delima

- Hijiki

- Murbei putih

- Nangka

- Alamanda

- Kesimpulan

- Daftar Pustaka 


\section{Pendahuluan}

Produk kosmetik digunakan untuk melindungi kulit dari agen-agen berbahaya, baik yang bersifat endogen ataupun eksogen, serta untuk memperbaiki penampilan kulit. Bahan yang terdapat dalam formulasi kosmetik dapat mendukung kesehatan, tekstur, dan integritas kulit, melembabkan, serta menjaga elastisitas kulit (Ishi, et. al., 2017).

Saat ini, banyak orang yang memiliki keinginan untuk memutihkan kulitnya. Hal tersebut mungkin disebabkan oleh beberapa faktor. Wanita dengan kulit yang lebih terang seringkali digunakan untuk mengiklankan berbagai produk, baik kosmetik maupun bukan kosmetik. Selain itu, banyak wanita yang terkenal, seperti di

industri hiburan yang memutihkan kulitnya. Hal tersebut lah yang menyebabkan tersebarnya sebuah stigma bahwa wanita dengan warna kulit yang lebih terang lebih cantik dan sukses. Orang yang menggunakan produk pemutih mempercayai bahwa warna kulit yang lebih putih dapat memberikan aura postif terhadap rasa percaya diri, persepsi terhadap kecantikan, bahkan terhadap upaya untuk mendapatkan suatu pekerjaan. (Olumide, 2010)

Sebelumnya, hidrokuinon seringkali digunakan dalam formulasi kosmetik pemutih, namun selama beberapa tahun terakhir, penggunaannya telah dilarang dengan alasan keamanan. Hidrokuinon telah dihubungkan dengan mutagenesis dan pengingkatan terjadinya ochronosis. Bahan lain yang seiring digunakan yaitu asam kojic arbutin, dan asam azelaic. Arbutin merupakan bentuk terglikosilasi dari hidrokuinon. Telah ditemukan derivatif baru senyawa ini, yaitu deoxyarbutin, yang memiliki sitotoksisitas yang lebih rendah dibandingkan dengan arbutin. Deoxyarbutin dihasilkan dengan cara menghilangan seluruh gugus hidroksil dari rantai sisi glukosa arbutin (Hu, et. al., 2009). Oleh karena itu, diperlukanlah bahan alami yang dapat menunjukan aktivitas memutihkan kulit. Berdasarkan beberapa penelitian, terdapat beberapa senyawa yang dihasilkan oleh bahan alami yang dapat menjadi alternatif dalam menghambat aktivitas tirosinase sehingga dapat menjadi bahan dalam pembuatan kosmetik herbal pemutih kulit (Smit, et. al., 2009).

Kosmetik herbal dengan bahan alami dianggap lebih berkualitas, ramah lingkungan, dan aman (Chen, 2009). Selain itu, kosmetik herbal juga memiliki efek samping yang lebih sedikit. Kosmetik herbal ini dapat diformulasikan dari satu atau lebih bahan alami dengan aktivitas yang diinginkan (Shivanand, et. al., 2010)

\section{Metode}

Referensi data yang digunakan pada review ini didapat dari jurnal mengenai kosmetik herbal yang dapat memutihkan kulit berdasarkan hasil penelitian yang telah dilakukan sebelumnya. Dalam proses pengumpulan data yang digunakan, dilakukan pencarian jurnal-jurnal acuan, baik nasional maupun internasional, melalui website yang menyediakan jurnal secara online. Adapun jurnal yang digunakan dianggap sebagai referensi. Jurnal referensi yang dipilih merupakan jurnal yang dirilis dalam rentang waktu sepuluh tahun terakhir, yaitu mulai tahun 2009 hingga 2019. 


\section{Hasil}

Tabel 1. Aktivitas Pemutih (Whitening) Beberapa Tanaman

\begin{tabular}{|c|c|c|c|c|c|}
\hline Judul Penelitian & $\begin{array}{l}\text { Penulis } \\
\text { (Tahun) }\end{array}$ & $\begin{array}{c}\text { Nama Tanaman / } \\
\text { Nama Latin }\end{array}$ & Senyawa Aktif & Metode & Hasil Penelitian \\
\hline $\begin{array}{l}\text { The potency of Indonesian } \\
\text { medicinal plants as } \\
\text { tyrosinase inhibitor and } \\
\text { antioxidant agent }\end{array}$ & $\begin{array}{l}\text { Batubara, et. } \\
\text { al. } \\
\text { (2010) }\end{array}$ & $\begin{array}{l}\text { Temulawak } \\
\text { (Curcuma } \\
\text { xanthorrhiza) }\end{array}$ & Vitamin C & $\begin{array}{l}\text { Enzimatik } \\
\text { (Mushroom } \\
\text { Tyrosinase) }\end{array}$ & $\begin{array}{l}\text { Memiliki aktivitas inhibisi } \\
\text { terhadap tirosinase }\end{array}$ \\
\hline $\begin{array}{l}\text { Formulation of liquorice } \\
\text { root extract (Glycyrrhiza } \\
\text { glabra L.) as skin } \\
\text { whitening cream }\end{array}$ & $\begin{array}{l}\text { Noor, et. al. } \\
\text { (2016) }\end{array}$ & $\begin{array}{l}\text { Akar Manis } \\
\text { (Glycyrrhiza } \\
\text { glabra) }\end{array}$ & Glabridin & $\begin{array}{l}\text { Enzimatik } \\
\text { (Mushroom } \\
\text { Tyrosinase) }\end{array}$ & $\begin{array}{l}\text { Memiliki aktivitas inhibisi } \\
\text { terhadap tirosinase }\end{array}$ \\
\hline $\begin{array}{l}\text { Pengaruh pemberian umbi } \\
\text { bengkuang (Pachyrrhizus } \\
\text { erosus I urban) terhadap } \\
\text { jumlah pigmen melanin } \\
\text { kulit mencit (Mus } \\
\text { musculus) yang } \\
\text { dipaparkan sinar matahari. }\end{array}$ & $\begin{array}{l}\text { Fitrah, et. al. } \\
\text { (2015) }\end{array}$ & $\begin{array}{l}\text { Bengkuang } \\
\text { (Pachyrhizus } \\
\text { erosus) }\end{array}$ & $\begin{array}{l}\text { Triterpen } \\
\text { Saponin } \\
\text { Flavonoid }\end{array}$ & $\begin{array}{l}\text { Hewan Percobaan } \\
\text { (Mencit) }\end{array}$ & $\begin{array}{l}\text { Pengolesan jus bengkuang } \\
\text { sebelum dipaparkan sinar } \\
\text { matahari dapat menurunkan } \\
\text { jumlah pigmen melanin yang } \\
\text { terbentuk pada kulit mencit. }\end{array}$ \\
\hline $\begin{array}{l}\text { Tyrosinase inhibitory } \\
\text { effect and inhibitory } \\
\text { mechanism of tiliroside } \\
\text { from raspberry }\end{array}$ & $\begin{array}{l}\text { Lu, et. al. } \\
\text { (2009) }\end{array}$ & $\begin{array}{l}\text { Raspberry } \\
\text { (Rubus idaeus L.) }\end{array}$ & Tilirosida & $\begin{array}{l}\text { Enzimatik } \\
\text { (Mushroom } \\
\text { Tyrosinase) }\end{array}$ & $\begin{array}{l}\text { Memiliki aktivitas inhibisi } \\
\text { terhadap tirosinase }\end{array}$ \\
\hline $\begin{array}{l}\text { Antioxidant activity and } \\
\text { melanogenesis inhibitory } \\
\text { effect of acerola fruit } \\
\text { (Malpighia glabra L.) } \\
\text { aqueous extract and its } \\
\text { safe use in cosmetics }\end{array}$ & $\begin{array}{l}\text { Wang, et. al. } \\
\text { (2015) }\end{array}$ & $\begin{array}{l}\text { Ceri Acerola } \\
\text { (Malpighia } \\
\text { emarginata) }\end{array}$ & $\begin{array}{l}\text { Vitamin C } \\
\text { Karoten } \\
\text { Niacinamides }\end{array}$ & $\begin{array}{l}\text { Enzimatik } \\
\text { (Mushroom } \\
\text { Tyrosinase) dan } \\
\text { menggunakan sel } \\
\text { melanoma tikus B16 }\end{array}$ & $\begin{array}{l}\text { Memiliki aktivitas inhibisi } \\
\text { terhadap tirosinase dan } \\
\text { dapat menginhibisi } \\
\text { terjadinya melanogenesis. }\end{array}$ \\
\hline $\begin{array}{l}\text { Tyrosinase inhibitory } \\
\text { activity and } \\
\text { thermostability of the } \\
\text { flavonoid complex from } \\
\text { Sophora japonica L } \\
\text { (Fabaceae). }\end{array}$ & $\begin{array}{l}\text { Lai, et. al. } \\
\text { (2014) }\end{array}$ & $\begin{array}{l}\text { Sophora japonica } \\
\text { (Sophora japonica, } \\
\text { L.) }\end{array}$ & $\begin{array}{l}\text { Rutin } \\
\text { Kuersetin }\end{array}$ & $\begin{array}{l}\text { Enzimatik } \\
\text { (Mushroom } \\
\text { Tyrosinase) }\end{array}$ & $\begin{array}{l}\text { Memiliki aktivitas inhibisi } \\
\text { terhadap tirosinase }\end{array}$ \\
\hline
\end{tabular}


D. Bashirah dan N.A. Putriana, Majalah Farmasetika, 4 (4) 2019, 119-127

\begin{tabular}{|c|c|c|c|c|c|}
\hline Judul Penelitian & $\begin{array}{l}\text { Penulis } \\
\text { (Tahun) }\end{array}$ & $\begin{array}{c}\text { Nama Tanaman / } \\
\text { Nama Latin }\end{array}$ & Senyawa Aktif & Metode & Hasil Penelitian \\
\hline $\begin{array}{l}\text { Tyrosinase inhibitory } \\
\text { activity and } \\
\text { thermostability of the } \\
\text { flavonoid complex from } \\
\text { Sophora japonica L } \\
\text { (Fabaceae). }\end{array}$ & $\begin{array}{l}\text { Lai, et. al. } \\
\text { (2014) }\end{array}$ & $\begin{array}{l}\text { Sophora japonica } \\
\text { (Sophora japonica, } \\
\text { L.) }\end{array}$ & $\begin{array}{l}\text { Rutin } \\
\text { Kuersetin }\end{array}$ & $\begin{array}{l}\text { Enzimatik } \\
\text { (Mushroom } \\
\text { Tyrosinase) }\end{array}$ & $\begin{array}{l}\text { Memiliki aktivitas inhibisi } \\
\text { terhadap tirosinase }\end{array}$ \\
\hline $\begin{array}{l}\text { Inhibition of melanin } \\
\text { content by punicalagins in } \\
\text { the super fruit } \\
\text { pomegranate (Punica } \\
\text { granatum) }\end{array}$ & $\begin{array}{l}\text { Rana, et. al. } \\
\text { (2013) }\end{array}$ & $\begin{array}{l}\text { Delima } \\
\text { (Punica granatum) }\end{array}$ & Punicalagain & $\begin{array}{l}\text { Pengujian in vitro } \\
\text { menggunakan } \\
\text { model kultur } \\
\text { jariangan Melan-a }\end{array}$ & $\begin{array}{l}\text { Pucinalgin secara langsung } \\
\text { dapat mereduksi melanin } \\
\text { yang terkandung dalam } \\
\text { jaringan Melan-a }\end{array}$ \\
\hline $\begin{array}{l}\text { Whitening effects of 4- } \\
\text { hydroxyphenethyl alcohol } \\
\text { isolated from water boiled } \\
\text { with Hizikia fusiformis } \\
\text { produksi melanin dalam } \\
\text { jaringan melanoma B16 }\end{array}$ & $\begin{array}{l}\text { Jang, et. al. } \\
\text { (2014) }\end{array}$ & $\begin{array}{l}\text { Hijiki } \\
\text { (Hizikia fusiformis) }\end{array}$ & $\begin{array}{l}\text { 4- } \\
\text { hydroxyphenethyl } \\
\text { alcohol }\end{array}$ & $\begin{array}{l}\text { Enzimatik } \\
\text { (Mushroom } \\
\text { Tyrosinase), } \\
\text { menggunakan } \\
\text { jaringan melanoma } \\
\text { tikus B16, dan } \\
\text { secara kolorimetri } \\
\text { serta pengamatan } \\
\text { visual terhadap } \\
\text { hiperpigmentasi } \\
\text { yang diinduksi oleh } \\
\text { UVB kulit kulit tikus } \\
\text { belanda. }\end{array}$ & $\begin{array}{l}\text { Memiliki aktivitas inhibisi } \\
\text { terhadap tirosinase, dapat } \\
\text { menginhibisi aktivitas } \\
\text { produksi melanin dalam } \\
\text { jaringan melanoma B16 dan } \\
\text { dapat menyebabkan } \\
\text { depigmentasi pada kulit } \\
\text { tikus belanda yang } \\
\text { mengalamami } \\
\text { hiperpigmentasi akibat UVB. }\end{array}$ \\
\hline $\begin{array}{l}\text { White mulberry (Morus } \\
\text { alba) : a brief } \\
\text { phytochemical and } \\
\text { pharmacological } \\
\text { evaluations account }\end{array}$ & $\begin{array}{l}\text { Zafar, et. al. } \\
\text { (2013) }\end{array}$ & $\begin{array}{l}\text { Murbei Putih } \\
\text { (Morus alba) }\end{array}$ & Mulberroside $\mathrm{F}$ & $\begin{array}{l}\text { Enzimatik } \\
\text { (Mushroom } \\
\text { Tyrosinase) dan } \\
\text { dengan pengujian in } \\
\text { vitro menggunakan } \\
\text { model kultur } \\
\text { jariangan Melan-a }\end{array}$ & $\begin{array}{l}\text { Memiliki aktivitas inhibisi } \\
\text { terhadap tirosinase dan } \\
\text { dapat menginhibisi produksi } \\
\text { melanin dalam jaringan } \\
\text { Melan-a }\end{array}$ \\
\hline
\end{tabular}




\begin{tabular}{|c|c|c|c|c|c|}
\hline Judul Penelitian & $\begin{array}{l}\text { Penulis } \\
\text { (Tahun) }\end{array}$ & $\begin{array}{c}\text { Nama Tanaman / } \\
\text { Nama Latin }\end{array}$ & Senyawa Aktif & Metode & Hasil Penelitian \\
\hline $\begin{array}{l}\text { Potency of jack fruit } \\
\text { leaves as tyrosinase } \\
\text { inhibitor }\end{array}$ & $\begin{array}{l}\text { Rayendra, et. } \\
\text { al. } \\
\text { (2016) }\end{array}$ & $\begin{array}{l}\text { Nangka } \\
\text { (Artocarpus } \\
\text { heterophyllus) }\end{array}$ & $\begin{array}{l}\text { Artocarpin } \\
\text { Artocarpanone }\end{array}$ & $\begin{array}{l}\text { Enzimatik } \\
\text { (Mushroom } \\
\text { Tyrosinase) }\end{array}$ & $\begin{array}{l}\text { Memiliki aktivitas inhibisi } \\
\text { terhadap tirosinase }\end{array}$ \\
\hline $\begin{array}{l}\text { Isolation, identification, } \\
\text { and tyrosinase inhibitory } \\
\text { activities of the } \\
\text { extractives from } \\
\text { Allamanda cathartica }\end{array}$ & $\begin{array}{l}\text { Yamauchi, et. } \\
\text { al. } \\
\text { (2011) }\end{array}$ & $\begin{array}{l}\text { Alamanda } \\
\text { (Allamanda } \\
\text { cathartica) }\end{array}$ & Glabridin & $\begin{array}{l}\text { Enzimatik } \\
\text { (Mushroom } \\
\text { Tyrosinase) }\end{array}$ & $\begin{array}{l}\text { Memiliki aktivitas inhibisi } \\
\text { terhadap tirosinase }\end{array}$ \\
\hline
\end{tabular}

\section{Pembahasan}

Pada kulit, melanosit terletak pada lapisan basal yang memisahkan dermis dan epidermis. Satu molekul melanosit dikelilingi oleh sekitar 36 keratinosit. Bersama-sama, mereka membentuk suatu kesatuan melanin epidermal. Melanin disimpan dalam kompartemen melanosomal. Pigmen melanin ini merupakan suatu polimer yang dihasilkan dalam melanosome dan disintesis dari asam amino L-tirosin yang dikonversi oleh enzim tirosinase menjadi dopakuinon. Saat bereaksi dengan sistein, dopakuinon membentuk 2- atau 5-S-sistenildopa yang menghasilkan prekurson benzotiazin polimer pheomelanin merah atau kuning. Pada umumnya, campuran polimer pheo- dan eumelanin dihasilkan dan disimpan pada matriks protein melanosomal. Beragamnya warna kulit pada manusia menunjukan bahwa komposisi campuran melanin bergantung pada banyak hal. Namun, adanya perubahan pada produksi melanin dapat menyebabkan berbagai masalah hiperpigmentasi seperti melasma, post inflammatory hyperpigmentation $(\mathrm{PIH})$, dan bitnik pada wajah. Tak hanya itu, perubahan produksi melanin juga dapat menimbulkan masalah depigmentasi seperti vitiligo (Smit, et. al., 2009).

\section{Temulawak}

Temulawak (Curcuma xanthorrhiza) merupakan spesies dari Zingiberaceae yang secara empiris seringkali bagian rimpangnya digunakan sebagai pengobatan tradisional. Kandungan vitamin $\mathrm{C}$ yang terkandung dalam temulawak meunjukkan efek agen pembasmi jerawat dan juga pemutih kulit. Temulawak kini banyak digunakan sebagai bahan dasar kosmetik pemutih dalam bentuk produk masker wajah, losion, dan krim wajah (Coal, et. al., 2010).

\section{Akar Manis}

Ekstrak akar Manis (Glycyrrhiza glabra) mengandung glycyrrhizin (10-25\%), liquiritin, liquiritigenin, isoliquiritigenin, isoliquiretin, glizirhizat, glabrenen acid and glabridin. Glabridin, merupakan sebuah senyawa fenol yang memiliki sifat antioksidan, neuroprotektif, antiinflamasi, entieksim, antipruitis, serta agen pemutih (Damle, 2014). 


\section{Bengkuang}

Bengkuang (Pachyrhizus erosus) memiliki keuntungan untuk menjaga kesehatan kulit dan menghilangkan sel kulit mati. Bengkuang juga mengandung vitamin $\mathrm{C}$ yang dapat menutrisi kulit. Bengkuang saat ini seringkali digunakan sebagai bahan pembuatan masker yang befungsi untuk menyegarkan wajah dan mencerahkan kulit (Fitrah, et. al., 2015)

\section{Raspberry}

Tilirosida, senyawa alami yang berasal dari raspberry, dapat menghambat aktivitas tirosinase intrasel secara signifikan dan produksi melanin dengan sitotoksisitas yang rendah pada sel B16. Hal ini mendukung bahwa tiliroside berpotensi menjadi agen pemutih kulit yang di industry farmasi dan kosmetik (Lu, et. al., 2009).

\section{Ceri acreola}

Ekstrak air dari ceri acreola lebih efektif dalam meinhibisi aktivitas tirosinase dibandingkan dengan arbutin. Hal ini dapat dikarenakan oleh kandungan vitamin C, karoten, dan niacinamide yang tinggi. Efek ini terjadi karena adanya penurunan trosinase intrasel pada tingkatan mRNA. Uji keamanan menunjukan bahwa ekstrak air tanaman ini bersifat aman dan tidak menyebabkan iritasi pada kulit manusia (Wang, et. al., 2015).

\section{Sophora japonica}

Ekstrak tanaman ini merupakan agen penginhibisi tirosinase yang poten, ditunjukan karena pada konsentrasi $0,1 \%$, ekstrak ini memiliki aktiitas inhibisi tirosinase yang lebih besar dibandingkan dengan asam askorbat dan hidrokuinon 1 \% (Lai, et. al., 2014).

\section{Delima}

Punicalagin yang terkandung dalam ekstrak buah delima sebanyak $20 \%$ dapat mengurangi kandungan melanin dalam sel dan tidak bersifat sitotoksis (Rana, et. al., 2013).

\section{Hijiki}

Suatu senyaawa fenol berupa 4- hydroxyphenethyl alcohol (4-HPEA) yang diisolasi dari ekstrak air Hizikia fusiformis dinyatakan memiliki aktivitas inhibisi terhadap tyrisonase. Selain itu, produksi melanin pada sel melanoma juga berkurang tanpa adanya toksisitas pada sel (Jang, et. al., 2014). 


\section{Murbei Putih}

Daun dari tanaman murbei putih (Morus alba) mengandung polifenol yang setelah dilakukan pengujian secara in vitro, menunjukan bahwa tanaman ini memiliki sifat depigmentasi. Pengujian telah dilakukan di China dengan menggunakan arbutin sebagai standar. Hasil penelitian menunjukan bahwa ekstrak murbei putih dengan dosis $100 \mu \mathrm{g} / \mathrm{ml}$ dapat menginhibisi tirosinase sebesar $70 \%$ sementara arbutin membutuhkan dosis $138 \mu \mathrm{g} / \mathrm{ml}$ (Yang, et. al., 2012).

Tak hanya daunnya, fraksi air dan etanol dari akar murbei putih menunjukkan efikasi depigmentasi yang lebih besar dibandingkan dengan asam kojic sebagai kontrol positif. Inhibisi tirosinase ini dapat disebabkan oleh pembentukan ikatan hidrogen dari gugus hidroksil senyawa fenol yang terkandung dalam ekstrak akar murbei putih dengan situs aktif pada enzim (Hanh, et. al., 2017)

\section{Nangka}

Ekstrak daun nangka muda memiliki aktivitas poten sebagai penginhibisi tirosinase. Aktivitas itu dikarenakan adanya kandungan artocarpin dan artocarpanone yang merupakan golongan flavonoid. Namun, aktivitas yang ditunjukkan oleh ekstrak daun nangka muda tidak berbeda secara signifikan dengan asam kojic (Rayendra, et al., 2016).

Bagian kulit dari buah nangka juga mengandung beberapa flavonoid yang memiliki aktivitas sebagai penginhibisi tirosinase. Senyawa ini dapat menghambat oksidasi Itirosine dan levodopa dalam mekanisme melanogenesis (Juwita, et. al., 2013).

\section{Alamanda}

Berdasarkan penelitian, terdapat lima senyawa baru yanh ditemukan dalam batang tanaman allamanda, yaitu glabridin, new lignin, naringenin, kaempferol, dan allamandicin. Diantara senyawa-senyawa tersebut, glabridin memiliki aktivitas inhibisi tirosinase yang paling poten. Bahkan, glabridin memiliki aktivitas yang lebih kuat dibandingkan asam kojic dengan efek depigmentasi 15 kali lebih baik (Yamauchi, et. al, 2011).

\section{Kesimpulan}

Terdapat berbagai tanaman yang memiliki aktivitas untuk memutihkan kulit, diantaranya yaitu temulawak, akar manis, bengkuang, raspberry, ceri acerola, sophora japonica, delima, hijiki, marbei putih, nangka, dan alamanda. Tanaman-tanaman tersebut berpotensi untuk dijadikan bahan dalam pembuatan kosmetik herbal. 


\section{Daftar Pustaka}

Chen, Q. 2009. Evaluate the effectiveness of the natural cosmetic product compared to chemical-based products. International Journal of Chemistry. 1:57-59.

Batubara, I., Darusman L. K., Mitsunagam T., Rahminiwati M., dan Djauhari, E. 2010. The potency of Indonesian medicinal plants as tyrosinase inhibitor and antioxidant agent. Journal of Biological Sciences. $10: 138-144$.

Damle, M. 2014. Glycyrrhiza glabra (Liquorice) - a potent medicinal herb. International Journal of Herbal Medicine. $2: 132-136$.

Fitrah, S., Lintong, P. M., dan Loho, L. L. 2015. Pengaruh pemberian umbi bengkuang (Pachyrrhizus erosus I urban) terhadap jumlah pigmen melanin kulit mencit (Mus musculus) yang dipaparkan sinar matahari. Jurnal e-Biomedik. Vol. 3 (1) : 216 - 220.

Hanh, N. T. M., Phung, N. K. P., dan Phuong, Q. N. D. 2017. Studying on tyrosinase inhibition activity of some Vietnamese folk plants aims to use in skin-whitening cosmetics. American Journal of Plant Sciences. 8 : 1319 - 1328.

Hu, Z. M., Zhou Q., Lei T. C., Ding S. F., dan Xu S. Z. 2009. Effects of hydroquinone and its glucoside derivates on melanogenesis and antioxidation : biosafety as skin whitening agents. Journal of Dermatological Science. 55 : $179-184$.

Ishi, H. S., Pawar, S. P., dan Patil, S. T. 2017. A research : design, development and evaluation of herbal skin lightening cream. World journal of pharmacy and pharmaceutical sciences. Vol. 6 (6) : $992-1003$.

Jang, M. S., Park, H. Y., dan Nam, K. H. 2014. Whitening effects of 4-hydroxyphenethyl alcohol isolated from water boiled with Hizikia fusiformis. Food Science and Biotechnology. Vol. 23 (2) : $555-560$.

Juwita, N. K., Djajadisastra, J., dan Azizahwati. 2011. Uji penghambatan tirosinase dan stabilitas fisik sediaan krim pemutih yang mengandung ekstrak kulit batang nangka (Artocarpus heterophyllus). Majalah Ilmu Kefarmasian. Vol. 2 (2) : 105 - 125.

Lai, J. S., Lin, C. C., dan Chiang, T. M. 2014. Tyrosinase inhibitory activity and thermostability of the flavonoid complex from Sophora japonica $L$ (Fabaceae). Tropical Journal of Pharmaceutical Research. Vol. 13 (2) : 243 - 247.

Lee, S. H., Choi, S. Y., Kim, H., Hwang, J. S., Lee, B. G., Gao, J. J., Kim, S. Y. 2002. Mulberroside $\mathrm{F}$ isolated from the leaves of Morus alba inhibits melanin biosynthesis. Biological and Pharmaceutical Bulletin. Vol. 25 (8) : 1045 - 1048.

Lu, Y. H., Chen, J., Wei, D. Z., Wang, Z. T., dan Tao, X. Y. 2009. Tyrosinase inhibitory effect and inhibitory mechanism of tiliroside from raspberry. Journal of Enzyme Inhibiton and Medicinal Chemistry. Vol. 24 (5) : $1154-1150$. 
Noor, S. U., Faridah, dan Michico. 2016. Formulation of liquorice root extract (Glycyrrhiza glabra L.) as skin whitening cream. Jurnal Tumbuhan Obat Indonesia. Vol. $9(2)$ : $93-99$.

Olumide, Y. M. 2010. Use of skin lightening creams. British Medical Journal. $341: 1-4$.

Rana, J., Diwakar, G., Saito, L., Scholten, J. D., dan Mulder, T. 2013. Inhibition of melanin content by punicalagins in the super fruit pomegranate (Punica granatum). International Journal of Cosmetic Science. 64 : 445 - 453.

Rayendra, R., Wientarsih, L., Priosoeryanto, B. P., dan Gunawan, H. 2016. Potency of jack fruit leaves as tyrosinase inhibitor. International Journal of Sciences : Basic and Applied Research. Vol. 30 (4) : $351-357$.

Shivanand, P., Nilam, M., Viral, D. 2010. Herbs play an important role in the field of cosmetics. International Journal of PharmTech Research. 2 : 632 - 639.

Smit, N., Vicanova, J., dan Pavel S. 2009. The hund for natural skin whitening agents. International journal of molecular sciences. $10: 5326-5349$.

Wang, L., Li, F., He, C., Dong, Y., dan Wang, Q. 2015. Antioxidant activity and melanogenesis inhibitory effect of acerola fruit (Malpighia glabra L.) aqueous extract and its safe use in cosmetics. Asian Journal of Chemistry. Vol. 27 (3) : 957 - 960.

Yamauchi, K., Mitsunaga, T., dan Batubara, I. 2011. Isolation, identification, and tyrosinase inhibitory activities of the extractives from Allamanda cathartica. Natural Resources. 2: 167 - 172.

Yang, Z., Wang, Y., Wang, Y.; Zhang, Y. 2012. Bioassay-guided screening and isolation of a-glucosidase and tyrosinase inhibitors from leaves of Morus alba. Food Chemistry. $131: 617-622$.

Zafar, M. S., Muhammad, F., Javed, I., Akhtar, M., Khaliq, T., Aslam, B., Waheed, A., Yasmin, R., dan Zafar, H. White mulberry (Morus alba) : a brief phytochemical and pharmacological evaluations account. International Journal of Agriculture \& Biology. Vol. $15(3):: 612-620$. 